\title{
INTERNATIONAL SECURITY CHALLENGES IN THE PERCEPTION OF RUSSIAN STUDENTS*
}

\author{
D.E. Slisovskiy, N.P. Medvedev \\ Peoples' Friendship University of Russia (RUDN University) \\ Miklukho-Maklaya St., 6, Moscow, 117198, Russia \\ (e-mail: de373@mail.ru; medvedev_rudn@mail.ru)
}

\begin{abstract}
How are the security issues perceived and evaluated not only by the global world leaders, experts, and scientists, but also by representatives of different social groups? Can their opinions and ideas change anything and reduce the level of international tension, or nothing depends on them? Answers to these questions are the methodological key to understanding the complexity of what is happening in the contemporary world considering the challenges of its global and local security. There must be something encouraging and reducing misunderstandings and mistrust in the field of peace-keeping and harmonization of international relations, even though we recognize the high level of influence of propaganda on the attitudes of people in different countries to the issues of security and other relevant questions in both Russia and throughout the world. The article presents the results of the analysis of the data of a number of surveys conducted among Russian students to find out their attitudes to the issues of global, regional, information and personal security. Based on the sociological research the authors describe how the younger generations (students) in Russia today react to the news on international security issues, how they interpret basic concepts of security and their meanings, what are their expectations, feelings and intentions, goals and fears. The results of the analysis of the students' ideas and representations of the international security issues prove a more positive perception of the future directions of international cooperation and provide more grounds to hope for the joint efforts of the leading countries of the world to counter security threats than one can expect relying on the mass media information, politicians' forecasts and expert community's estimates. Perhaps, this part of the younger generations worldview can be considered irrational and even naive. However, one should take into account that the current social status of this group will inevitably change in the near future, which promises that the Russian participation in the public and political international activities will help to decrease the level of international tension and confrontation. Thus, there are hopes for the development of dialogue forms of relations and paths to trust and joint efforts to counter threats and challenges of global security.
\end{abstract}

Key words: security threats; regional security; personal security; Russia-US relations; Russia-EU relations; Russian students perception of security challenges; Russian students perception of the Ukrainian crisis

Information attacks (the so-called 'stove-piping') in the public discourse concerning global, regional, and information security issues at the level of both professional discussions and daily conversations are becoming more common and notable in the Russian, European, American, and Asia-Pacific media space [see: 10; 15]. Such stove-piping activity were mentioned and considered not only during the Security Conference held

* C D.E. Slisovskiy, N.P. Medvedev, 2018. 
in Munich in February 2017, but also during the VI Moscow Conference on International Security (MCIS-2017) held in April 26-27 [see: 23].

Security issues have always played [see: $13 ; 14]$ and still play a significant role in the Russian information space and scientific debates. Today no one in Europe, America or Russia would disagree with the statement that security issues have become a rather difficult problem to solve. The speech of Bill Gates at the Munich conference sounded especially cautious and alarming. He found it necessary to claim that the world leaders today think differently about public health and national security [5]. Such an approach is not a response to the existing challenges but rather a just recognition of the new international reality lacking a single power center or ruling authorities to study and accept different opinions and ways to interpret and solve security challenges.

As the level of the global, regional, and information security tensions increases, the development of a security strategy as the national doctrine becomes an urgent task not only in the USA [see: 21], but also in Russia [see: 20]. We believe that is the reason why more and more attention of researchers and mass media is given to the future perspectives and ways to interpret security challenges in terms of imagination and positions of political and government leaders, experts, and, finally, certain social groups, which are structured according to the political, social, ideological, and other diverse grounds and interests. Taking into account such a situation, we can refer to the selection of analytical papers of the Munich Security Conference [see: 1], and a series of articles in the leading European media [see: $2 ; 3]$. The Russian position was made clear in the speech of the Minister of Foreign Affairs of the Russian Federation Sergey Lavrov [8], and in the speech of the Minister of Defense of the Russian Federation, Army General Sergei Shoigu at MCIS-2017 [19].

Thus, the study of the theoretical and practical aspects of the impact of the mass media and contemporary information technologies on the younger generations of Russia, especially students, should be rather common than exceptional part of the analysis of international security challenges. For instance, a survey aimed at understanding how the global, regional, and information security is perceived by Russian students and foreign students in Russia can be a significant case.

Under the current conditions of international security, it is important to learn about the students' perception of the global, regional, and information security challenges. Such a topic of the research is justified also in terms of comparison of the results of our study with the data of the all-Russian survey conducted by 'Levada-Center' $[6 ; 7]$ to reveal the attitudes of the Russians not only to security issues, but also to other topics related to the international security, such as attitudes towards the USA, the EU, Ukraine, the North Korean nuclear incident, etc. We conducted a survey of more than 600 students from different universities; the sample consisted of both Russian students from different regions of Russia and foreign students from a dozen of countries studying Russian and other foreign languages (English, French, Chinese, Arabic, etc.). The results of the study presented below include the authors estimates and the expert opinions of the representatives of the target group (Alina Boroday, David Khachayan and 
Rodion Beresnev) that participated in the research, so that to outline the younger Russian generations understanding of security issues, their thoughts and preferences.

Based on the formalized data obtained in the survey, we made the following conclusions, theoretical and practical generalizations.

- Even the increased level of global tensions in the contemporary world together with the significant decline of trust between countries and their leaders, the growing threats to international security and the on-going rise of the flow of information and disinformation, could not seriously upset the younger generations in Russia, stimulate their aggressive behavior and hostile attitudes towards the leading actors of the international order such as the USA and European Union, and also to Ukraine and other countries.

- Despite serious concerns in the Russian youth's perception of global, regional, and information security, there are no empirical indicators of the persistent images of 'the enemy' as if acting inside or outside the country and threatening it.

- International security and the related threats are not an issue of priority life importance for the majority of students. For them, the insecure realities are emotional rather than rational image. At the same time, such realities for students are not just a topic 'bloated' by state propaganda or mass media, but a serious concern. However, the content, supporting mechanisms and structure of the security threats are still not clear enough for the majority of students.

- Unsatisfied curiosity and interest of students to the issues of international security certainly stimulates their desire to discuss such issues more openly and more relevantly for their level of knowledge.

We believe that the results of the survey can be discussed only if, first, one trusts the survey data, and second, we note the grounds for their critique when we present and analyze them. The first question of the survey conducted a week after February 20, 2017, was as follows: "What do you know or what have you heard about the Security Conference in Munich?". The results show that $97 \%$ of the respondents haven't heard anything about this particular conference and about the fact that this conference is held annually, unites high-ranking politicians, scientists and global experts, and is supported financially and organizationally by both the participating countries and international mass media holdings. For the remaining 3\% of the respondents the conference itself and the issues discussed became a kind of 'ground noise' at the background of the huge and rapid flow of all other international and national news. A similar question concerning the Security Conference in Moscow in April 2017 gave somewhat different results: $60,4 \%$ have not heard anything, while $39,2 \%$ have heard something about the event, but did not follow the information. The explanation for these differences in the perception of information messages on specific events concerning security issues can be found in the fact that the second conference was held in Moscow, and the students who reside in this city had the opportunity to learn about it.

Such responses of students are fully predictable and not difficult to explain for they could be easily predicted. The social-political 'deafness' of the youth is not determined mainly by the timeframe (albeit a short one, separating one event from 
another) or by quite aggressive and sophisticated presentation of the increased flow of information on the topic in the mass media. Political apathy, infantilism, and low level of social and political interest and responsibility of students and younger generations in general in the countries with stable political regimes and advanced and sustainable economies has long ago been noted by many scientists and experts [see: 17; 22]. However, under all situations and conditions, manifestations and motives of the youth and students do not dependent so clearly and directly on information attacks.

The survey findings on the issues of the international security were also quite predictable and easy to explain. $98 \%$ of the respondents agreed that the security issue is the real, obvious, and pressing. In April 2017, during the Moscow conference, 83,3\% of the respondents agreed that this problem is a significant and acute one. There are no significant differences in the opinions observed as compared to the previous survey: this problem is still obvious, clear and pressing, its ratings in the sample remain the same. However, as the comparison of the two groups of the responses of students shows, their answers concerning the new information about the international conferences prove the total mass ignorance of the information messages on security, which were declared in the mass media, public discussions, and political debate. At the same time, we revealed an equally widespread acceptance of the importance of the security issue as a private problem, even a personal and individual. There are indications that for the youth and students security is, on the one hand, a great and essential problem of the contemporary world in its broadest manifestations; on the other hand, this problem becomes visible for them only through personal experience that makes the younger generations consider the problem of security as acute and of a great importance. However, due to the fact that Russian students in general do not have such an experience, they do not demonstrate sustainable and dramatic empathy and perception of the security as an acute social problem.

There is a certain contrast between the students' attitudes and the views common for politicians and experts concerning the question whether or not international terrorism is the main threat of our times. Only $20,5 \%$ of the respondents consider international terrorism a major threat for the contemporary society. The same share of the respondents $(20,5 \%)$ names the high level of mistrust between countries and their leaders as the main threat to the global situation and peace-keeping. About $50 \%$ of the students believe that concerns in the field of international relations can determine serious security risks. And $37,5 \%$ of the students find the threats in the unresolved internal contradictions of the country.

According to the students' opinions, political and economic challenges rank the first places among the threats to the security. Specific needs and forms to ensure international and regional security became obvious under the aggravation of the situation concerning the policy of North Korea. We succeeded in tracing the students' perception of the development of the Korean crisis. The opinions of the students on the statement of the US President "North Korea is a global threat and a problem that we have to finally solve" divided as follows: $55,7 \%$ of the responders agreed with this estimate of the US President Donald Trump, $16,5 \%$ disagreed with it, and $27,7 \%$ refused to express their opinion 
on the problem and the statements of President Trump. In such responses of the students, we consider the most important the nuances of the national perception of the causes and consequences of the situation even if the students do not seek and are not ready to be involved in this process at least at the level of mass media. Fragmentary, incomplete information, and its expressionless format play an important role in not letting the students to understand clearly the problems and contradictions of the protracted crisis surrounding the nuclear threat to the world posed by the North Korean government; however the situation becomes more clear due to the fact that the unresolved conflict and unwillingness of the leading countries and all the parties involved to solve the conflict by negotiations jeopardizes the lives of millions of people.

One can expect that the media policy in Russia as being controlled by the state and pro-government structures should lead to anti-American sentiments in the worldview of the students. This line in the propaganda campaign and politics has long been discussed by the critics and opponents of the Kremlin. In fact, we see that $44,2 \%$ express mutual trust, another $18,8 \%$ would like to share the responsibility for the global peace and stability with the USA. Moreover, $63 \%$ of the respondents tend to mutual respect and responsible behavior of Russia and the USA in relation to the fates of their own peoples and the world in general. The remaining group of respondents (pragmatics, who found it difficult to express an opinion, and so on) cannot be called Americanophobes or opponents of the American way of life and political strategy in the international arena.

Let us admit that the attitudes towards the USA expressed in the students' opinions are not a very interesting phenomenon to focus on. It reflects the worldview priorities of a segment of the Russian population concerning the USA, which seems to differ from what many people in Europe, America, and even Russia tend to think. It is no so important that such a sociological snapshot of views and relations considers not a large proportion of the average population. What is really important is that we talk about the future generations of the country that express its hopes and creates an illusion of changing attitudes and expectations after the Crimea and imposition of sanctions. This is another reality, an absolutely new reality for the future. The youth and students demonstrate a gradual improvement in the attitudes towards the USA determined by the illusions of the changing global situation. This is a very high share $(72 \%$ against $28 \%$ of those who advocate absolutely positive and pragmatic relations of Russia with the USA) characterized by the unexpressed positive connotations in the students' feelings. The results of the situational responses and clarifications show that (though with $28,8 \%$ of those who refused to express their opinion) just a small share equal to the statistical error expressed skepticism and indifference concerning the Russia-US relations. Thus, we come to the conclusion that there are no students with hostile feelings, in particular, towards the USA [see also: 11; 12].

We believe that the clarifying question "Who destabilizes Europe?" allow to justify and reinforce our findings. Thus, just $10,1 \%$ of the respondents tend to consider the USA as playing a destabilizing role in Europe, while 8,6\% assign the same role to the European Union. 
In Russia, we are not prone to illusions that the majority of Russian students are aware and interested in security issues, in the subjects that threaten social security. However, we believe it necessary to learn what students think about the current political and global agenda. It is also not surprising that western observers do not focus on this topic for even in Russia itself this problem is hardly recognized and analyzed through the identification of public expectations and sentiments [16]. Nevertheless, this is the reality of the Russian political and social life. We are convinced that through the prism of security issues we can not only clearly see the most acute political contradictions, but also change the attitudes to the seemingly sustainable and long-accepted ideologemes at both global and regional levels.

In the survey, we also asked the students about the crisis in Ukraine. It is quite possible that the students' responses to the question and the very wording of it were influenced by propaganda and the general information policy of the Russian mass media. However, the availability of different information (printed materials, TV-news, and especially the Internet) in English and other languages in the European and American media reduces the effect of the single-channel and unilateral perception and understanding of the situation in Ukraine. The students estimate of the security threats from the specific region (Ukraine) are not obvious though quite careful. The most important and noteworthy are the responses of $21 \%$ of the respondents, who have their own opinion regarding the main culprits of the crisis in Ukraine, while $35 \%$ refused to express a clear opinion, and 41,3 accuse Western countries of the crisis in Ukraine. Thus, 56\% of the students do not lay the blame for the crisis in Ukraine on the European and American leaders. We come to the conclusion that students have a clear and reasonable explanation of the current situation in Ukraine as not having definite culprits.

We can be disappointed by a kind of outsiders' attitude of the students to the seemingly topical issues in the news and especially to the very problem of security. When we consider the youth and students in Russia, there are some signs of infantilism, political indifference, social passivity, generational dependency, even laziness and apathy with regard to politics, while there are sharp social and economic contradictions both in the country and in the world. Perhaps, that is why we witness frequent practices and relapses of overtures to the youth for the sake of winning their cheap authority from party leaders, state officials, and representatives of scientific and expert communities. However, at the same time we hear irritated sentiments that the younger generations today are much more authoritarian and much more aggressive than it was $20-30$ years ago. Such critics say that the today's youth is very primitive, very happy with themselves, adhere to very consumer and cynical views, and are satisfied with what is happening around [6]. It seems so strange that this part of the Russian expert community are not able to think as freely as the youth, and to express more positive thoughts to the younger generations.

We believe that the high share of the students who are not exposed to the information attacks and are unaware of the acute social problems related to the national security can be explained by the current social-political situation in the country and 
in the global world. Though the blame for such situation is often laid only on the corrupt, selfish, and arrogant state authorities, which has put itself above the law, this is just an echo of the idealized legend, which has had a devastating impact even on its creators. Due to paltry experience and knowledge, the students in Russia are not yet capable of conducting a comprehensive analysis of complex issues and processes. Their images of the threats to the world are quite vague. These ideas are mainly formed by the contemporary information civilization characterized by the dominance of aggressive communicative technologies that can easily heat up protest sentiments. In this situation, the Russian students despite clear evidence of their indifference to the acute issues of our times manage to understand the significance of the security problem for the world. Their adequate response and desire to find a way to mutual respect and responsibility is their unconscious contribution to the solution of this problem. There are no hostile feelings towards the USA, European countries, and Ukraine in the youth's worldview. They expect the same attitude to themselves and to their country yet not doing anything except getting knowledge and professional skills.

We do admit the limitations of our survey results and of the methodology used to obtain and interpret the data. We also recognize the need for regular measurements of the students' attitudes and perception of relevant information about important political and historical events in Russia and worldwide. At the same time, it is noteworthy that the students themselves express readiness and interest in further studies of the younger generations' values, priorities, fears and interpretations of the security issues. We have already scheduled a program of further activities for the detailed public discussion of the research findings of the project "History and Politics" (2017-2018) [see also: 18].

We will be grateful for the feedback to those experts who are ready to share with us their concerns and observations and will appreciate their thoughtful, open-minded but rigorous criticism. We would also like to express our gratitude to our assistants and active participants of the study, the RUDN University and the Russian Presidential Academy of National Economy and Public Administration (RANEPA) students.

\section{REFERENCES}

[1] Analyses and Press Reports. https:// www.securityconference.de/en/news/article/what-happenedat-the-munich-security-conference-2017-analyses-and-press-reports.

[2] Applebaum A. The specter of Trump in Munich. https://www.washingtonpost.com/news/globalopinions/wp/2017/02/19/the-specter-of-trump-in-munich/?postshare $=2561487530149481 \&$ tid= ss_tw-bottom\&utm_term=1e618b8aa0a6.

[3] Delcker J. Germany will take own time to boost defense, Merkel tells Pence. http://www.politico.eu/ article/germany-will-take-own-time-to-boost-defense-merkel-tells-pence.

[4] Europe is starting to get serious about defense. https://www.securityconference.de/debatte/ monthly-mind/detail/article/monthly-mind-februar-2017-wie-umgehen-mit-trump-was-europajetzt-tun-und-lassen-sollte.

[5] Gates B. When nature is a terrorist. Editorial Board. Washington Post. 2017; 23.

[6] Gudkov L. Vozhdi i natsiya [Leaders and the nation]. http://www.levada.ru /2017/02/21/vozhdi-inatsiya/print (In Russ.). 
[7] Kuritsa uzhe nemnogo ptitsa [Chicken is already a kind of bird]. http://www.levada.ru/2017/ 02/03/kuritsa-uzhe-nemnogo-ptitsa (In Russ.).

[8] Lavrov S. I hope world chooses post-West order. https://www.washingtonpost.com/news/globalopinions/wp/2017/02/19/the-specter-of-trump-in-munich/?postshare $=2561487530149481 \&$ tid $=$ ss_tw-bottom\&utm_term=.1e618b8aa0a6.

[9] Medvedev N.P. Vliyanie ekstremizma i terrorizma na konfliktogennost Severo-Kavkazskogo regiona [The impact of extremism and terrorism on the conflict potential of the North Caucasus]. Voprosy Politologii. 2015; 2 (In Russ.).

[10] Munich Security Report 2018. To the Brink — and Back? https://www.securityconference.de/ en/discussion/munich-security-report/munich-security-report-2018.

[11] Narbut N.P., Trotsuk I.V. Neighboring countries' images: Persistent stereotypes of the Russian student youth. RUDN Journal of Sociology. 2017; 17 (3).

[12] Narbut N.P., Trotsuk I.V. Socialnoe samochuvstvie molodezhi postsocialisticheskih stran (na primere Rossii, Kazakhstana i Chekhii): sravnitelnyj analiz strahov, nadezhd i opasenij (Chast 2) [The social well-being of the post-socialist countries' youth (on the example of Russia, Kazakhstan and Czech Republic): Comparative analysis of fears and hopes (Part 2)]. RUDN Journal of Sociology. 2018; 18 (2) (In Russ.).

[13] Obzor konferentsiy, proshedshih v 2012-2016 gg. v Moskve [Review of the conferences held in 2012-2016 in Moscow]. http://mil.ru/mcis/2012-2016.htm (In Russ.).

[14] Podborka materialov 5 Moskovskoy konferentsiyi po mezhdunarodnoy bezopasnosti, 2016 [Selection of papers of the 5-th Moscow International Security Conference]. https://ria.ru/trend/ conference_international_security_27042016.htm.

[15] Post-Truth, Post-West, Post-Order? www.securityconference.de/de/debatte/munich-securityreport/munich-security-report-2017.

[16] Slizovskiy D.E. Paradoksalnost molodezhnyh nastroyeniy i otnosheniy k vyboram-2016 [Paradoxicality of the youth's attitudes and relations to the election-2016]. Communicology. 2016; 5 (In Russ.).

[17] Slizovskiy D.E., Amiantov A.A. Sotsialno-politicheskiye predpochteniya molodezhi 18 -20 let: kontrast mezhdu zayavleniyami i dannostyu [Social-political preferences of 18 -20 year-old youth: The contrast between statements and reality]. Locus. 2016; 4 (In Russ.).

[18] Slizovskiy D.E., Medvedev N.P., Shulenina N.V., Kashin, V.M. Issledovatelskij proekt: otnoshenie molodezhi k revolyutsii 1917 goda i povliyaet li ono na vybory 2018 [Research project: The youth's attitudes towards the Revolution of 1917, and whether it will affect the presidential elections of 2018]. Politicheskie Issledovanija. 2017; 1 (In Russ.).

[19] Speech of the Minister of Defense of the Russian Federation, Army General Sergei Shoigu. https://www.youtube.com/watch?v=Sb6Z2RTziXY (In Russ.).

[20] Strategiya natsionalnoy bezopasnosti Rossiyskoy Federatsii do 2020 goda [The National Security Strategy of the Russian Federation up to 2020]. https://rg.ru/2009/05/19/strategia-dok.html (In Russ.).

[21] The National Military Strategy of the United States of America, 2015. http://pentagonus.ru/ load/3/strategii_i_koncepcii/the_national_military_strategy_of_the_united_states_of_america_ 2015/31-1-0-1287.

[22] Trotsuk I.V. Some 'indicators' to 'measure' patriotism in the contemporary world. Serbian Sociological Review. 2017; LI (3).

[23] VI Moscow Conference on International Security. http://eng.mil.ru/en/mcis/index.htm.

[24] What happened at the Munich Security Conference 2017? http://www.economist.com/news/ europe/21717391-under-pressure-donald-trump-herbivores-are-thinking-about-eating-meateurope-starting. 
DOI: $10.22363 / 2313-2272-2018-18-3-443-451$

\title{
ПРОБЛЕМЫ МЕЖДУНАРОДНОЙ БЕЗОПАСНОСТИ ГЛАЗАМИ РОССИЙСКОГО СТУДЕНЧЕСТВА*
}

\author{
Д.Е. Слизовский, Н.П. Медведев \\ Российский университет дружбы народов \\ ул. Миклухо-Маклая, 6, Москва, 117198, Россия \\ (e-mail: de373@mail.ru; medvedev_rudn@mail.ru)
}

\begin{abstract}
Как мыслят и ощущают политику безопасности не только мировые лидеры, эксперты и ученые, но и представители самых разных социальных групп, зависит ли от их мнения что-либо для понижения градуса международной напряженности? Ответы на эти вопросы - методологический ключ к пониманию всей сложности происходящего сегодня в мире в контексте его глобальной и локальной безопасности. На этом пути, несомненно, должно быть что-то обнадеживающее и снижающее градус недопонимания и недоверия в деле поддержания мира и согласия, даже если мы признаем высокий уровень влияния пропаганды на отношение граждан к вопросу безопасности и связанным с ней проблемам как в России, так и во всем мире. В статье представлен анализ данных, полученных в ходе опросов российских студентов на тему глобальной, региональной, информационной и личной безопасности. Показано, как современное молодое поколение (студенчество) в России реагирует на новости по проблемам международной безопасности, как трактует для себя это понятие и его смыслы, чего ожидает в будущем и к чему стремится. Результаты социологического анализа позволяют утверждать, что оценки российских студентов демонстрируют гораздо более позитивное видение перспективных направлений международного сотрудничества и надежд на совместные усилия ведущих стран мира в деле противостояния угрозам безопасности, чем можно было бы ожидать, учитывая доминирующие дискурсы медийного пространства, политических прогнозов и оценок экспертного сообщества. Возможно, данный срез молодежных представлений не рационален и даже наивен. Однако следует учитывать, что лишь пока социальный статус этой группы не высок, но в ближайшем будущем он вырастет, что обещает важную роль российского участия в общественной и политической международной практике с точки зрения понижения градуса международной конфронтации. Все это дает основания надеяться на развитие и утверждение диалоговых форм отношений, укрепление настроя на путь доверия и совместного противодействия угрозам и вызовам глобальной безопасности.
\end{abstract}

Ключевые слова: угрозы безопасности; региональная безопасность; личная безопасность; российско-американские отношения; отношения России и ЕС; восприятие российскими студентами проблем безопасности; мнения российских студентов об украинском кризисе

* С Слизовский Д.Е., Медведев Н.П., 2018. 